\title{
Effect of Indole on the Mono-oxygenase System in Rat Liver Microsomes
}

\author{
Masaaki Watanuki, Masashi SAKaI, Kiyoshi Tohyama \\ and Masahiko MutAI
}

Yakult Central Institute for Microbiological Research,

1796 Yaho, Kunitachi, Tokyo 186, Japan

Received July 10, 1981

\begin{abstract}
The effect of indole on the mono-oxygenase systems was studied in liver microsomes from control, indole-, phenobarbital- and 3-methylcholanthrene-treated rats. No induction was observed by indole of either cytochrome P-450 or the mono-oxigenase activities. It was, however, a potent competitive inhibitor of aniline hydroxylase $(K i=0.03 \sim 0.04 \mathrm{~mm})$. A spectroscopic study showed that this competition occurred at the aniline binding site on cytochrome P-450. The inhibitory effect was observed on aminopyrine $N$-demethylase with less efficiency $(K i=0.1 \sim 0.5 \mathrm{~mm})$ and on benzo[a]pyrene hydroxylase. These inhibitions were also observed in the systems of mice, rabbits and monkeys. The physiological effect of indole on liver drug metabolism was also discussed.
\end{abstract}

Indole generated in the intestinal tract is metabolized in liver to indican (indoxylsulfate) which is excreted into the urine. The excretion of excessive urinary indican is observed in some abnormal conditions such as bacterial overgrowth in the small intestine, ${ }^{1,2)}$ protein malabsorption ${ }^{3)}$ and high intake of beef. ${ }^{4}$ The effect of indole on mono-oxygenase activities in liver has been reported by several investigators. Induction of aryl hydrocarbon hydroxylase activities $^{5)}$ and also dimethylnitrosamine demethylase activities ${ }^{6)}$ by indole and its derivatives have been reported in rat liver microsomes. In addition, Shertzer reported the inhibition of mono-oxygenase activities by indole derivatives in liver microsomes from phenobarbital-treated rabbits. ${ }^{7)}$

From these reports, it is supposed that indole generated excessively in the intestinal tract enhances the activities of drug metabolism in liver on the one hand. However, we must consider the possibility that the enhanced activities are inhibited by the indole. Therefore, to elucidate the physiological effect of indole on liver drug metabolism, we have performed kinetic studies on the inhibition of aniline hydroxylase and aminopyrine $\mathrm{N}$ demethylase by indole using liver microsomes from rats treated with various inducers including indole.

\section{MATERIALS AND METHODS}

Chemicals. Indole, 3-methylcholanthrene and aniline hydrochloride were purchased from Wako Pure Chemical Industries, Ltd. (Osaka, Japan), sodium phenobarbital and aminopyrine from Sanko Seiyaku Co., Ltd. (Tokyo, Japan), benzo[a]pyrene from Sigma Chemical Co. (St. Louis, MO), and 3-hydroxybenzo[a]pyrene from the NCI Chemical Repository, IIT Research Institute (Chicago, IL).

Animal and treatment. Male Sprague-Dawley rats, 6 weeks old at sacrifice, were maintained on MF diet (Oriental Yeast Co., Tokyo, Japan) and water ad libitum.

The animals received daily intraperitoneal injections of indole at a dose of $117 \mathrm{mg} / \mathrm{kg}$, sodium phenobarbital at 75 $\mathrm{mg} / \mathrm{kg}, 3$-methylcholanthrene at $25 \mathrm{mg} / \mathrm{kg}$ or olive oil at 5 $\mathrm{ml} / \mathrm{kg}$ (for the control) over a period of 3 days.

Preparation of microsomes. Microsomes were prepared following the method described by Werringloer et $a l^{8)}$ Rats fasted for $18 \mathrm{hr}$ were decapitated $24 \mathrm{hr}$ after the last injection and the livers were perfused in situ with $20 \mathrm{ml}$ of ice-cold $0.15 \mathrm{M} \mathrm{NaCl}$ solution. A homogenate was prepared as a $1: 4(\mathrm{w} / \mathrm{v})$ dilution of a liver mince in $0.25 \mathrm{M}$ sucrose using a Potter-Elvehjem-type glass-teflon homogenizer. The microsomes were isolated by a 1 hour centrifugation at $100,000 \times g$ of the supernatant resulting from sequential $10 \mathrm{~min}$ centrifugations of the homogenate at 
600,8000 and $18,000 \times g$. The pellet obtained after washing in $0.15 \mathrm{M} \mathrm{KCl}$ of the $100,000 \times g$ sediment and recentrifugation was suspended to protein concentrations of $25 \sim 45 \mathrm{mg} / \mathrm{ml}$ in a buffer medium containing $0.05 \mathrm{M}$ Tris$\mathrm{HCl}, \mathrm{pH} 7.4$, and $0.25 \mathrm{~m}$ sucrose. Depending on the experiment, the suspension containing $30 \%$ glycerol was stored at $-20^{\circ} \mathrm{C}$ for a few days without any changes of the enzyme activities. The protein concentration was determined by Lowry's method. ${ }^{9)}$

Enzyme assays. Mono-oxygenase activities were determined using the method previously described with some modifications. ${ }^{10 \sim 12)}$ Formation of $p$-nitrophenol from aniline hydroxylase was measured in $1.25 \mathrm{ml}$ of a reaction mixture consisting of $100 \mathrm{~mm}$ potassium phosphate buffer (pH 7.3), $3 \mathrm{mM} \mathrm{MgCl}_{2}$, microsomes containing $1 \mathrm{nmol}$ cytochrome P-450, $1 \mathrm{~mm}$ aniline hydrochloride and $0.5 \mathrm{~mm}$ NADPH. After $1 \mathrm{~min}$ of preincubation, the enzyme reaction was performed at $37^{\circ} \mathrm{C}$ for $5 \mathrm{~min}$. The reaction was initiated by adding NADPH and was stopped by adding $0.6 \mathrm{ml}$ of $15 \%$ trichloroacetic acid solution. One $\mathrm{ml}$ of the supernatant from centrifugation at $1,200 \times g$ for 10 min was incubated with $0.25 \mathrm{ml}$ of $1 \%$ phenol in $0.5 \mathrm{M}$ $\mathrm{NaOH}$ and $0.5 \mathrm{ml}$ of $2 \mathrm{M} \mathrm{Na} \mathrm{CO}_{3}$ at $37^{\circ} \mathrm{C}$ for $30 \mathrm{~min}$. Absorbance was measured at $620 \mathrm{~nm}$.

Formation of formaldehyde from aminopyrine $\mathrm{N}$ demethylase was determined in the same reaction mixture and under the same conditions used for the assay of aniline hydroxylase except that $1 \mathrm{~mm}$ aminopyrine was used instead of $1 \mathrm{~mm}$ aniline. The reaction was stopped by adding $0.5 \mathrm{ml}$ of $20 \% \mathrm{ZnSO}_{4}$ and $0.5 \mathrm{ml}$ of a saturated solution of $\mathrm{Ba}(\mathrm{OH})_{2}$. One $\mathrm{ml}$ of the supernatant from centrifugation at $1,200 \times g$ for $10 \mathrm{~min}$ was incubated with $0.4 \mathrm{ml}$ of Nash reagent at $60^{\circ} \mathrm{C}$ for $15 \mathrm{~min}$. Absorbance was determined at $415 \mathrm{~nm}$.

Benzo $[a]$ pyrene hydroxylase activity was determined in $1 \mathrm{ml}$ of a reaction mixture consisting of $100 \mathrm{~mm}$ potassium phosphate buffer, $3 \mathrm{~mm} \mathrm{MgCl}_{2}, 0.5 \mathrm{~mm} \mathrm{NADPH}, 80 \mu \mathrm{M}$ benzo[ $a]$ pyrene in $20 \mu \mathrm{l}$ of acetone and microsomes (usually containing $0.8 \mathrm{nmol}$ cytochrome P-450). After $1 \mathrm{~min}$ of preincubation, the enzyme reaction was performed at $37^{\circ} \mathrm{C}$ for $2 \mathrm{~min}$. The reaction was initiated by adding benzo[ $a]$ pyrene and stopped by adding $1 \mathrm{ml}$ of acetone and $3.25 \mathrm{ml}$ of hexane. The mixture was shaken at $37^{\circ} \mathrm{C}$ for 30 min. A $2.0 \mathrm{ml}$ aliquot of the organic phase was extracted with $4.0 \mathrm{ml}$ of $1 \mathrm{~N} \mathrm{NaOH}$ for $1 \mathrm{~min}$. The amount of 3hydroxybenzo $[a]$ pyrene formed was determined from the intensity of fluorescence at $522 \mathrm{~nm}$ activated at $396 \mathrm{~nm}$.

Spectral analysis. Cytochrome P-450 was determined by the method of Omura and Sato, using $91 \mathrm{~mm}^{-1} \cdot \mathrm{cm}^{-1}$ as the molar extinction coefficient for the reduced cytochrome P-450-CO complex. ${ }^{13)}$ Substrate induced difference spectroscopy was performed using $4 \mu \mathrm{M}$ cytochrome P-450 as described by Jefcoate ${ }^{14)}$ with a Hitachi 557 Double Wavelength Spectrophotometer.

\section{RESULTS}

\section{Induction of mono-oxygenase activities}

Treatment of rats with indole at the same dose level as reported by Arcos et al. ${ }^{5)}$ caused neither significant induction of cytochrome P450 in liver microsomes nor a shift of the absorption peak of the $\mathrm{CO}$ difference spectrum (Table I). Liver weights, after the three injections of indole, were slightly less than the controls. As has been reported, phenobarbitaland 3-methylcholanthrene-treatments were efficient in inducing cytochrome P-450. Approximately a 40 percent gain in liver weight was observed in phenobarbital-treated rats.

Aniline hydroxylase and aminopyrine $\mathrm{N}$ demethylase activities were not induced by the treatment with indole. Although these activities were always slightly higher in microsomes of indole-treated rats, the differences of

Table I. Induction of Cytochrome P-450 And Its Activities in RAT LIVER Microsomes

The experiments were performed as described in MATERIALS AND METHODS. The number of experiments performed is shown in parenthesis. Values are means \pm S.E.

\begin{tabular}{|c|c|c|c|}
\hline Treatment & $\begin{array}{c}\mathrm{P}-450 \\
\text { (nmol/mg prot.) }\end{array}$ & $\begin{array}{l}\text { Aniline hydroxylase } \\
\text { (nmol/min/mg prot.) }\end{array}$ & $\begin{array}{l}\text { Aminopyrine } N \text {-demethylase } \\
\text { (nmol } / \mathrm{min} / \mathrm{mg} \text { prot.) }\end{array}$ \\
\hline Control & $0.77 \pm 0.06$ & $1.10 \pm 0.31$ & $7.11 \pm 0.82$ \\
\hline Indole & $0.75 \pm 0.02$ & $1.17 \pm 0.29$ & $7.92 \pm 1.31$ \\
\hline Phenobarbital & $1.59 \pm 0.16^{* * *}(9)$ & $2.29 \pm 0.26^{* * *}$ & $10.17 \pm 0.73^{*}(4)$ \\
\hline 3-Methylcholanthrene & $1.42 \pm 0.15 * * *(9)$ & $1.52 \pm 0.11 * *$ & $8.28 \pm 1.57$ \\
\hline
\end{tabular}

$* p<0.05 . * * \quad p<0.01 . * * * \quad<0.001$ by Student's $t$-test. 
the mean values were not significant for the Student's $t$-test. Phenobarbital and 3-methylcholanthrene were also significantly potent inducers of these activities except 3-methylcholanthrene for aminopyrine $N$-demethylase activity.

\section{Inhibition by indole of liver microsomal mono- oxygenase activities}

Aniline hydroxylase and aminopyrine $\mathrm{N}$ demethylase are representative monooxygenases of type II and type I substrates, respectively, in liver microsomes. Direct inhibitory effects of indole on these activities were examined kinetically using microsomes from control, indole-, phenobarbital- and 3methylcholanthrene-treated rats. Table II shows the inhibition types with indole of the mono-oxygenase activities. Aniline hydroxylase was competitively inhibited by indole. This was observed in every kind of microsome independently of the induction. The $K i$ values of indole calculated for the activity were around $0.03 \mathrm{~mm}$ to $0.04 \mathrm{~mm}$ in these preparations which had different $V_{\max }$ and $\mathrm{Km}$-values for the enzyme reactions. On the other hand, indole revealed a slightly different mode of action on aminopyrine $N$-demethylase depend- ing on the preparation used. When microsomes from phenobarbital- and 3-methylcholanthrene-treated rats were used, the aminopyrine $N$-demethylase activity was competitively inhibited by indole. The indole, however, non-competitively inhibited the activities in microsomes from the control and indole-treated rats at the lower concentration $(0.2 \mathrm{~mm})$, while the higher concentration $(0.5 \mathrm{~mm})$ of indole showed competitive inhibition of these activities. The $K i$ values of indole for aminopyrine $N$-demethylase calculated were three to ten fold as much as those for aniline hydroxylase.

The effect of indole on another notable mono-oxygenase activity, aryl hydrocarbon hydroxylase activity, was studied. Table III shows that $0.2 \mathrm{~mm}$ indole showed approximately fifty percent inhibition of benzo $[a]$ pyrene hydroxylase activity in all the rat liver microsomes tested except the microsomes from 3-methylcholanthrene-treated rats of which the benzo[a]pyrene hydroxylase activity was about 10 fold as active as those of other preparations. No significant inhibition of this highly active hydroxylase was observed in the presence of lower concentrations of indole than $0.5 \mathrm{~mm}$.

Table II. Type of Inhibition and $K i$ OF Indole for Aniline HydroxylaSe and Aminopyrine $N$-Demethylase Activities in Various Microsomes

The $K i$ values of indole were calculated from Lineweaver-Burk plots performed in the presence of $0.08 \mathrm{mM}$ indole for aniline hydroxylase and in the presence of $0.2 \mathrm{~mm}(* 0.5 \mathrm{~mm})$ indole for aminopyrine $N$-demethylase. All the values represent the results of a typical experiment.




The inhibition of the mono-oxygenase activities by indole was observed also in microsomes from other mammals tested (Table IV). Aniline hydroxylase activities in liver microsomes prepared from non-treated rat, mouse (ICR), rabbit (Angoras white) and monkey (Cynamolgus irus) were decreased to 48, 38, 48 and 69 percent of the control levels, respectively, in the presence of $0.2 \mathrm{~mm}$ indole. As observed in the case of rat, the aminopyrine $N$ demethylase in other mammals was also rather insensitive to indole compared to the aniline hydroxylase. The corresponding values for the aminopyrine $N$-demethylase were $69,81,63$ and 73 percent of the control levels.

\section{TABLE III. INHIBITION BY INDOLE OF BENZO $[a]$ PYRENE HYDROXYLASE ACTIVITY}

Enzyme assays were performed as described in MATERIALS AND Methods except that $0.16 \mathrm{nmol}$ cytochrome P-450 was used for the assay of activities in 3methylcholanthrene-treated rats. Values are the results of a typical experiment but two independent experiments revealed similar results.

\begin{tabular}{lcrr}
\hline \multirow{2}{*}{ Treatment } & \multicolumn{3}{c}{ Relative activity $(\%)$} \\
\cline { 2 - 4 } & Indole $(\mathrm{mm}): 0$ & 0.2 & 1.0 \\
\hline Control & $100(0.48)^{*}$ & 40 & 17 \\
Indole & $100(0.49)$ & 41 & 2 \\
Phenobarbital & $100(0.89)$ & 37 & 11 \\
3-Methylcholanthrene & $100(4.41)$ & 95 & 51 \\
\hline
\end{tabular}

* nmol 3-hydroxybenzo[a]pyrene/min/mg prot.

\section{Binding of indole on cytochrome P-450}

Except for the minor type I difference spectra induced by indole at the concentrations lower than $0.5 \mathrm{~mm}$ in the microsomes from the control and indole-treated rats, indole induced type II difference spectra in every preparation revealed an absorption minimum at $388 \sim$ $390 \mathrm{~nm}$ and a maximum at $422 \sim 426 \mathrm{~nm}$. Slight shifts of the peaks were observed as the result of the treatments with various inducers.

Aniline induced a typical type II difference spectrum with an absorbance minimum at $397 \mathrm{~nm}$ and an absorbance maximum at



FIG. 1. Inhibition by Indole of Aniline Binding on Cytochrome P-450.

The substrate difference spectra induced by $0.12,0.22,1.22$ and $3.22 \mathrm{~mm}$ aniline were measured in the absence $(\boldsymbol{O})$ and the presence of $2 \mathrm{~mm}(\bigcirc)$ and $5 \mathrm{~mm}(\triangle)$ indole using 3methylcholanthrene induced microsomes at room temperature. The buffer system consisted of $50 \mathrm{~mm}$ Tris- $\mathrm{HCl}$ ( $\mathrm{pH} 7.4$ ), $0.15 \mathrm{M} \mathrm{KCl}, 10 \mathrm{mM} \mathrm{MgCl}_{2}$ and $2.7 \mu \mathrm{M}$ cytochrome P-450.

\section{Table IV. EfFect Of INDOle on Aniline Hydroxylase AND Aminopyrine $N$-DEMETHYLASE IN LiVer Microsomes FROM VARIOUS MAMMALS}

The values are the results of a typical experiment. Each experiment was performed independently. Animals used were a mouse (ICR), a rabbit (Angoras white), a monkey (Cynamolgus irus) and a rat as a control. The monkey liver was kindly presented by Dr. T. Fujiwara of the National Institute of Health, Higashi-murayama, Tokyo.

\begin{tabular}{|c|c|c|c|c|c|c|c|}
\hline \multirow{3}{*}{ Animals } & \multicolumn{4}{|c|}{ Aniline hydroxylase } & \multicolumn{3}{|c|}{ Aminopyrine $N$-demethylase } \\
\hline & Indole (mM) & 0 & 0.2 & 1.0 & 0 & 0.2 & 1.0 \\
\hline & \multicolumn{4}{|c|}{$(\mathrm{nmol} / \mathrm{min} / \mathrm{mg}$ prot. $)$} & \multicolumn{3}{|c|}{ (nmol/min/mg prot.) } \\
\hline Rat & & 0.71 & 0.34 & 0 & 8.74 & 6.00 & 3.30 \\
\hline Mouse & & 1.36 & 0.52 & 0.03 & 6.97 & 5.63 & 4.21 \\
\hline Rabbit & & 0.52 & 0.25 & 0.19 & 2.16 & 1.35 & 1.23 \\
\hline Monkey & & 0.42 & 0.29 & 0.26 & 2.38 & 1.74 & 0.88 \\
\hline
\end{tabular}


$430 \mathrm{~nm}$. This induction was prevented by indole. In the presence of the various concentrations of indole indicated, the absorbance differences between $430 \mathrm{~nm}$ and $394 \mathrm{~nm}$ induced by the various concentrations of aniline were measured and Lineweaver-Burk plots were made. Figure 1 shows the results for 3methylcholanthrene-treated rats. All three linear lines crossed each other on the $y$ axis. The $K i$ value calculated from these results was around $0.2 \mathrm{~mm}$. A similar result was obtained for the preparations from phenobarbital-treated rats.

\section{DISCUSSION}

Our present experiments showed that indole in olive oil injected at a dose of $117 \mathrm{mg} / \mathrm{kg}$ over 3 days caused no induction of either cytochrome $\mathrm{P}-450$ or the mono-oxygenase activities while treatment with phenobarbital or 3methylchoranthrene induced both of them (Table I). Arcos et al., however, reported the induction of aryl hydrocarbon hydroxylase activity on injecting indole in trioctanoin at the same dose $24 \mathrm{hr}$ before killing the animals. ${ }^{5)}$ As far as tested, the number of injections or the lower dose level $(75 \mathrm{mg} / \mathrm{kg})$ made no differences to the results. Probably, the absence of induction may be due to our use of different aged rats. We used young Sprague-Dawley rats (40 days old) while they used wealing ones (21 23 days old). Using very young Wister rats (30 days old), Evarts et al. observed the induction of cytochrome P-450 and the monooxygenase activities in rat microsomes on feeding indole. ${ }^{6)}$ In this case, however, there is another possibility that dietary indole affects liver microsomes in the forms of its derivatives because of the following reasons. We found that 5-hydroxytryptamine, a metabolite of tryptophan, injected three times intraperitoneally at a dose of $25 \mathrm{mg} / \mathrm{kg}$ induced cytochrome P-450 and both aniline hydroxylase and aminopyrine $N$-demethylase activities. In addition, tryptophan is synthesized from indole by tryptophan synthase in Esherichia coli. Furthermore, tryptophan has been report- ed to be an inducer of cytochrome P-450. ${ }^{15)}$

Shertzer reported the direct effect of indole on aniline hydroxylase in microsomes from phenobarbital-treated rabbits. ${ }^{7)}$ In the presence of $10 \mathrm{~mm}$ aniline as substrate, more than $500 \mu \mathrm{M}$ indole was required to get $50 \%$ inhibition of the activity. In our experimental system, $K i$ values of indole for aniline hydroxylase and aminopyrine $N$-dimethylase were approximately $30 \mu \mathrm{M}$ and $100 \sim 500 \mu \mathrm{M}$, respectively, depending on the preparations from rats after various treatments (Table II). The $K i$ values $(30 \sim 40 \mu \mathrm{M})$ for aniline hydroxylase were comparable to the $K s$ value of indole $(53.4 \mu \mathrm{M})$ reported by H. G. Shertzer for the rabbit liver cytochrome $\mathrm{P}-450,{ }^{7)}$ indicating that indole reacts with cytochrome P-450 in the concentration range of around $50 \mu \mathrm{M}$.

Indole revealed two types of inhibition of aminopyrine $N$-demethylase activities when microsomes from control and indole-treated rats were used (Table II). This was due to the heterogeneity of cytochrome P-450 contained in those microsomes. This heterogeneity was probably responsible for the type I different spectra observed in the same preparations.

Lineweaver-Burk plots of the aniline concentration versus the absorbance differences between $430 \mathrm{~nm}$ and $394 \mathrm{~nm}$ induced by aniline in the presence of $0,0.2$ and $5 \mathrm{~mm}$ indole revealed three straight lines which crossed each other on the $y$ axis (Fig. 1). This suggests the competition of indole and aniline on the same binding site. Such competition must occur between indole and benzo $[a]$ pyrene since the lower inhibitory activity of indole to benzo[ $a]$ pyrene hydroxylase was observed in the microsomes from 3-methylcholanthrene treated rats which show an extra-ordinarily high affinity to benzo[a]pyrene.

The concentration of indole in rat portal plasma was normally around $5 \mu \mathrm{M}$. It increased to approximately $50 \mu \mathrm{M}$ or more when the small intestine was perfused with KrebsRinger solution containing $5 \mathrm{~mm}$ indole. This elevated level of indole was observed after injection of $50 \mu \mathrm{mol}$ of tryptophan into rat caecum, indicating the possibility that the in- 
dole concentration in the portal plasma increases to these levels in some abnormal conditions. The elevated level of indole may be high enough to reveal the inhibition of aniline hydroxylase and other mono-oxygenases of type II substrates in rat liver since the $K i$ value of indole for the enzyme was approximately 30 to $40 \mu \mathrm{M}$. This inhibition was observed also in other mammalian systems (Table IV).

Therefore, some significant effects of indole on liver microsomal drug metabolisms are considered to occur in abnormal conditions such as bacterial overgrowth in the small intestine, protein malabsorption and high intake of beef.

\section{REFERENCES}

1) C. E. King and P. P. Toska, Gastroenterology, 76, 1035 (1979).

2) B. Miller, R. Mitchison, S. Tabaqchali and G. Neal, Eur. J. Clin. Invest., 2, 23 (1971).

3) N. J. Greenberger, S. Saegh and R. D. Ruppert, Gastroenterology, 55, 204 (1968).
4) H. Haenel, Am. J. Clin. Nutr., 23, 1433 (1970).

5) J. C. Arcos, S. C. Myers, B. J. Neuburger and M. F. Argus, Cancer Lett., 9, 161 (1980).

6) R. P. Evarts and M. H. Mostafa, Biochem. Pharmacol., 30, 517 (1981).

7) H. G. Shertzer, "Microsomes, Drug Oxidations, and Chemical Carcinogenesis," Vol. II, ed. by M. J. Coon, A. H. Conney, R. W. Estabrook, 'H. V. Gelboin, J. R. Gillette and P. J. O'Brien, Academic Press Inc., New York, N.Y., 1980, p. 889.

8) J. Werringloer and R. W. Estabrook, Arch. Biochem. Biophys., 167, 270 (1975).

9) O. H. Lowry, N. J. Rosebrough, A. L. Farr and R. J. Randall, J. Biol. Chem., 193, 265 (1951).

10) R. G. Hart and J. R. Fouts, Proc. Soc. Expl. Biol. Med., 114, 388 (1963).

11) T. Nash, Biochem. J., 55, (1953).

12) A. Y. H. Lu, R. Kuntzman, S. West, M. Jacobson and A. H. Conney, J. Biol. Chem., 247, 1727 (1972).

13) T. Omura and R. Sato, J. Biol. Chem., 239, 2370 (1964).

14) C. R. Jefcoate, "Methods in Enzymology," Vol. LII, ed. by S. P. Colowick and N. O. Kaplan, Academic Press Inc., New York, N.Y., 1978, p. 258.

15) R. P. Evarts and M. H. Mostafa, Food Cosmet. Toxicol., 16, 585 (1978). 